\title{
Assessment of Groundwater Quality for Irrigation Use and Evolution of Hydrochemeical Facies in the Yeshwanthapur Sub- Basin, Warangal Dist.
}

\author{
*B.Satheesh, S. Sateesh Kumar, K. Narender Reddy \\ Department of Geology Kakatiya University, Warangal-506 009. Telangana.
}

\begin{abstract}
The Yeshwanthapur is a sub-basin of Aler river basin with an aerial extent of 688 sq. kms with a perimeter of $136 \mathrm{kms}$. The study area comprises Archaean group of rocks represented by Peninsular Gneiss Complexes occupy major part of with grey and pink granite/gneisses. Assessment of groundwater quality for irrigation use and hydrochemical evolution of groundwater has been studied. Hydrochemical analysis has been carried out based on concentrations of $\mathrm{Ca}+\mathrm{Mg}+\mathrm{Na}+\mathrm{K}+\mathrm{Cl}+\mathrm{F}, \mathrm{So}-\mathrm{Co}-$ and $\mathrm{HCo}$, Sodium adsorption ratio (SAR) and Percent Sodium (\%Na) have been studied to evaluate suitability of irrigation use most of the area groundwater in the basin
\end{abstract}

Keywords: Groundwater quality, Hydrochemical analysis, Irrigation use, Yeshwanthapur sub-basin, Warangal.

\section{Introduction}

The Yeshwanthapur is a sub-basin of Aler river basin and forms part of Warangal district in Telangana with an aerial extent of $688 \mathrm{sq} . \mathrm{kms}$ with a perimeter of $136 \mathrm{kms}$. The sub-basin lies between north latitude $17^{\circ}$ $53^{\prime} 10^{\prime \prime}$ to $17^{\circ} 28^{\prime} 42^{\prime \prime}$ and east longitude $79^{\circ} 04^{\prime} 24^{\prime \prime}$ to $79^{\circ} 24^{\prime} 51^{\prime \prime}$ represented in parts of the Survey of India toposheet No's $56 \mathrm{O} / 1,56 \mathrm{O} / 2,56 \mathrm{O} / 5,56 \mathrm{O} / 6$, and $56 \mathrm{O} / 7$ (Fig.1). The north-western part of the study area at Venkiryala village is having maximum elevation of 516 meters above Mean Sea Level (MSL) and minimum at Thatipamula village having 240 meters above MSL with slope in NW to SE direction. The maximum length and width of Yeshwanthpur sub-basin is $49.3 \mathrm{kms}$ and $22.7 \mathrm{kms}$ respectively. Red and black cotton soils which dominated the area with a character of swelling clays integrated drainage networks with high density slope areas and so on causing rapid runoff leaving relatively little water for recharge. The investigated area receives scanty rain fall and has limited surface water resources. The climate of the surface of the sub-basin is semi-arid and receives an average rainfall of $765.80 \mathrm{~mm}$, out of which $90 \%$ is received during north western (June-Sep) monsoon period. The average temperature is $28+5^{\circ} \mathrm{C}$ on the basis of climatic classification the area falls under Semi-arid climatic zone (D-type). Geology of the study area comprises Archaean group of rocks represented by Peninsular Gneiss Complexes with grey and pink granite/gneisses occupy major part of the area and in many places leached calcium carbonate precipitates are found which are locally known as Kankar (Fig.2). They form hard layers just below the top soil and have high fluoride content. These deposits are associated with black and alkanlie soils. They are formed by the depositions of $\mathrm{CaCo} 3$ as nodular masses.

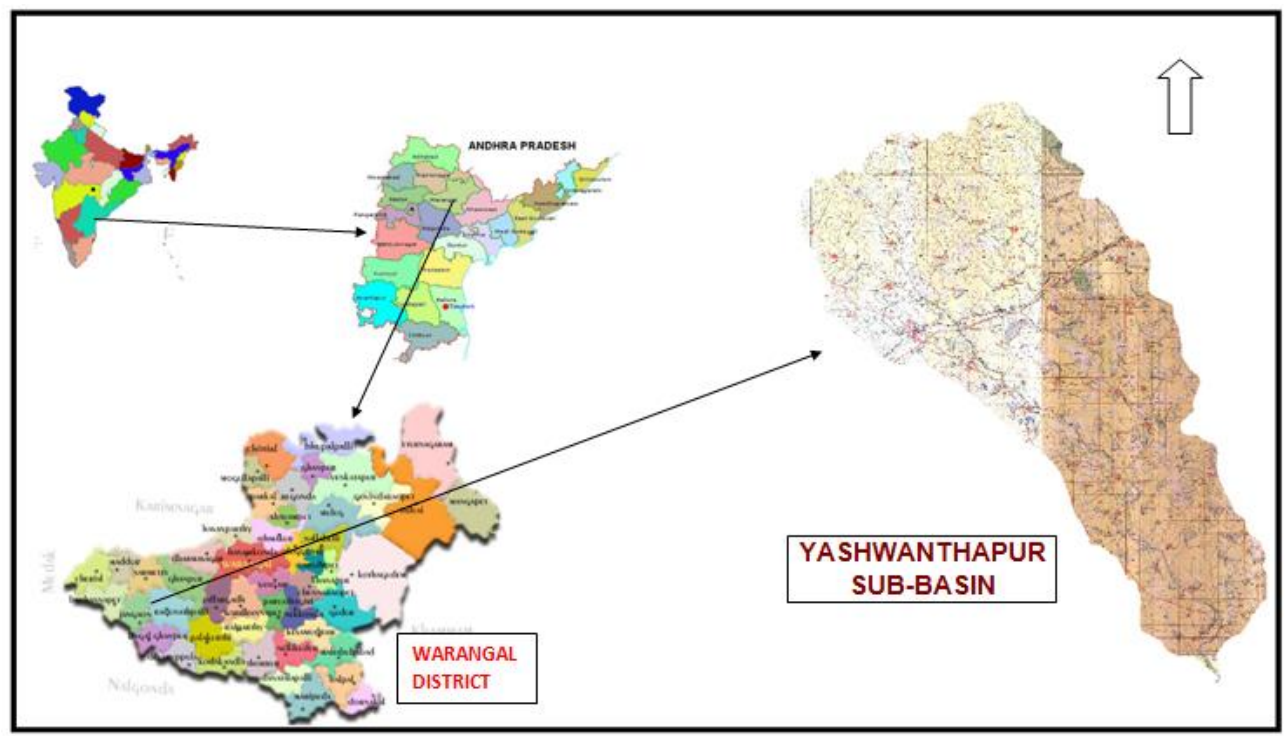

Fig. 1 Showing Location map the Study Area 


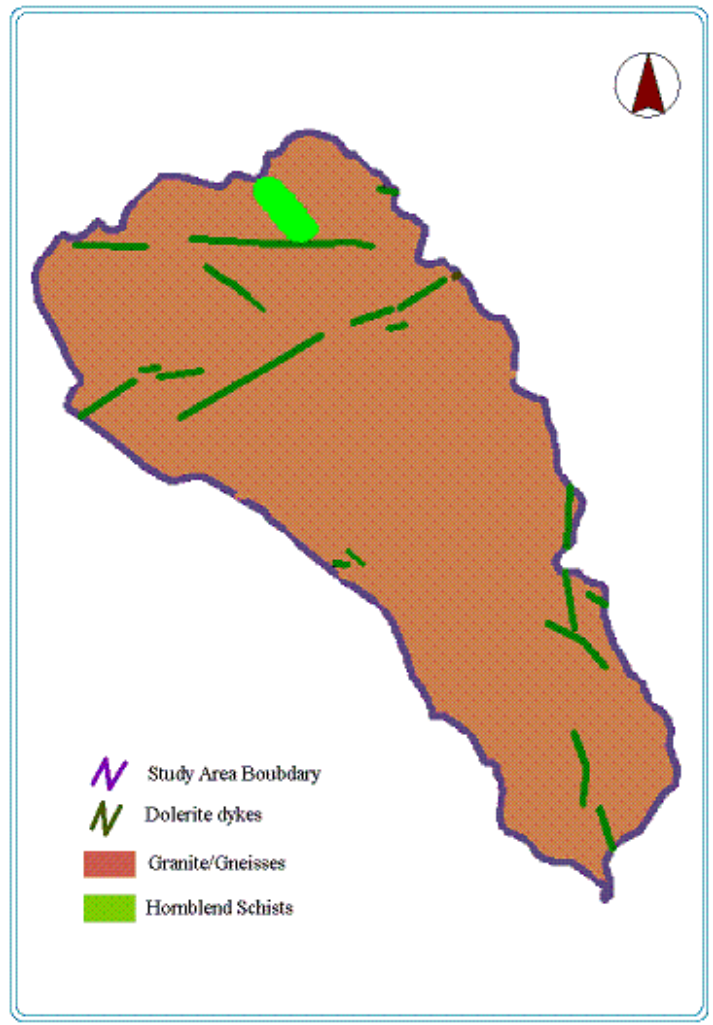

Fig.2 Showing Geology of the Area

\section{Experimental Methods}

Groundwater samples were collected at selected locations based on hydrogeomorphology all over the area of the sub-basin. Detailed hydrogeological investigations have been carried out to know the geochemical behavior and to assess the quality of groundwater in the area. 34 samples were collected in which 21 is from dug wells 13 from bore wells (Fig.3). Physical and chemical parameters of 34 samples were analysed to know the quality of water as per standards and the data is presented in Table.1 major iron concentrations were determined by using Bureau of Indian standards BIS (1991) and WHO international Standard (2006) methods.

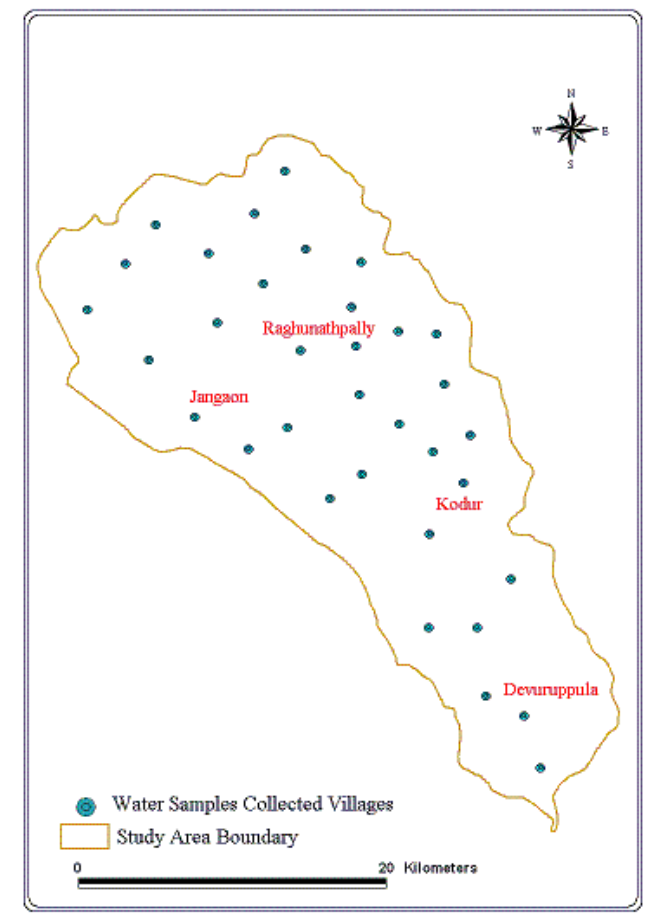

Fig. 3 Water sample locations in the study area 
Table 1. Chemical Analysis Data of Groundwater Samples of the Area

(Values are in ppm except TDS and EC)

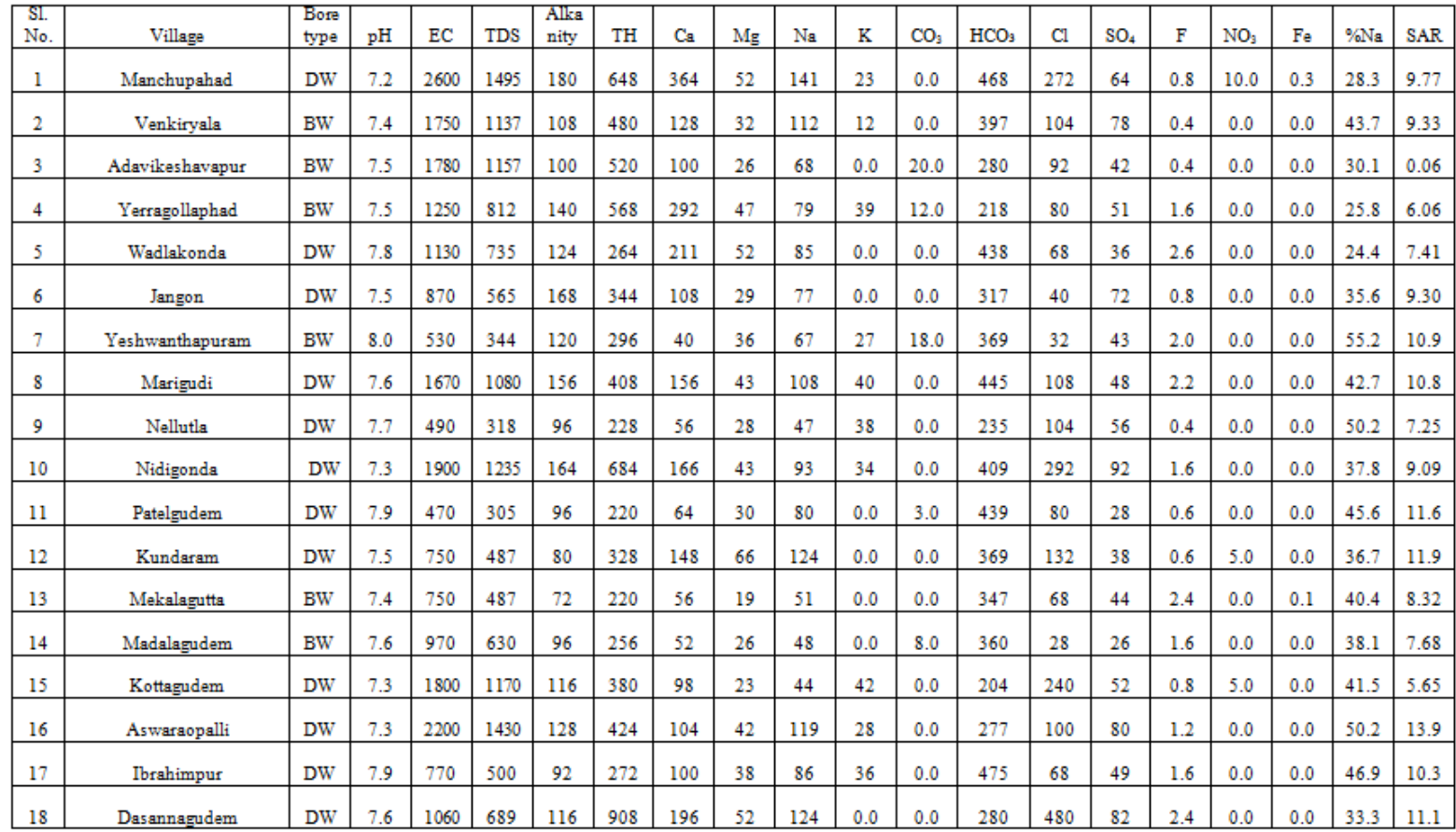

Table 1. Chemical Analysis Data of Groundwater Samples of the Area

(Values are in ppm except TDS and EC)

\begin{tabular}{|c|c|c|c|c|c|c|c|c|c|c|c|c|c|c|c|c|c|c|c|c|}
\hline $\begin{array}{l}\text { S1. } \\
\text { No. }\end{array}$ & Village & $\begin{array}{l}\text { Bore } \\
\text { type }\end{array}$ & $\mathrm{pH}$ & $\mathrm{EC}$ & TDS & $\begin{array}{l}\text { Alks } \\
\text { nity }\end{array}$ & $\mathrm{TH}$ & $\mathrm{Ca}$ & $\mathrm{Mg}$ & $\mathrm{Na}$ & $\mathrm{K}$ & $\mathrm{CO}_{3}$ & $\mathrm{HCO}_{3}$ & $\mathrm{Cl}$ & $\mathrm{SO}_{4}$ & $\mathrm{~F}$ & $\mathrm{NO}_{3}$ & $\mathrm{Fe}$ & $\% \mathrm{Na}$ & SAR \\
\hline 19 & Vildhi & DW & 7.1 & 1850 & 1202 & 88 & 400 & 68 & 64 & 61 & 22 & 12.0 & 390 & 136 & 43 & 0.4 & 0.0 & 0.0 & 38.6 & 7.50 \\
\hline 20 & Raghunathpally & BW & 7.5 & 2800 & 1820 & 132 & 416 & 328 & 44 & 72 & 56 & 0.0 & 185 & 300 & 62 & 1.2 & 0.0 & 0.0 & 25.6 & 3.22 \\
\hline 21 & Venkatapally & BW & 7.9 & 1240 & 806 & 176 & 224 & 28 & 24 & 52 & 29 & 0.0 & 292 & 96 & 71 & 2.0 & 5.0 & 0.0 & 60.9 & 10.2 \\
\hline 22 & Govardhanagiri & BW & 7.5 & 1230 & 799 & 120 & 500 & 100 & 81 & 112 & 05 & 0.0 & 334 & 76 & 28 & 1.4 & 0.0 & 0.0 & 39.3 & 11.7 \\
\hline 23 & ommala & DW & 7.5 & 3100 & 2015 & 196 & 804 & 32 & 31 & 27 & 13 & 12.0 & 372 & 292 & 32 & 1.8 & 0.0 & 0.0 & 38.8 & 4.81 \\
\hline 24 & Yella Reddy Gudem & BW & 7.4 & 920 & 598 & 140 & 372 & 192 & 78 & 96 & 39 & 0.0 & 488 & 48 & 47 & 1.8 & 0.0 & 0.0 & 33.3 & 8.26 \\
\hline 25 & Kanchanpally & $\mathrm{DW}$ & 7.6 & 1720 & 1118 & 188 & 612 & 136 & 67 & 82 & 18 & 19.0 & 302 & 88 & 26 & 0.8 & 0.0 & 0.0 & 33.0 & 8.13 \\
\hline 26 & anjipet & DW & 7.0 & 1600 & 1040 & 160 & 936 & 128 & 49 & 65 & 06 & 0.0 & 289 & 436 & 26 & 0.4 & 0.0 & 0.0 & 28.6 & 6.90 \\
\hline 27 & obbeta & $\mathrm{DW}$ & 7.5 & 1580 & 1027 & 100 & 364 & 60 & 43 & 34 & 09 & 0.0 & 427 & 128 & 61 & 2.4 & 5.0 & 0.0 & 29.5 & 4.73 \\
\hline 28 & Kodur & BW & 7.3 & 1840 & 1196 & 112 & 544 & 196 & 58 & 26 & 40 & 0.0 & 341 & 204 & 70 & 1.2 & 0.0 & 0.0 & 20.6 & 2.30 \\
\hline 29 & Padamati Thanda & DW & 6.8 & 2200 & 1430 & 80 & 608 & 320 & 34 & 49 & 26 & 0.0 & 488 & 168 & 83 & 1.8 & 0.0 & 0.0 & 17.5 & 3.68 \\
\hline 30 & Pedda Madur & BW & 7.2 & 2150 & 1400 & 164 & 228 & 64 & 40 & 80 & 11 & 0.0 & 390 & 90 & 45 & 0.4 & 5.0 & 0.0 & 46.7 & 11.0 \\
\hline 31 & Karavendi & $\mathrm{DW}$ & 7.4 & 1350 & 877 & 116 & 346 & 98 & 38 & 66 & 0.0 & 5.0 & 359 & 130 & 33 & 1.4 & 5.0 & 0.1 & 32.7 & 8.00 \\
\hline 32 & Devuruppula & $\mathrm{DW}$ & 7.3 & 2064 & 1342 & 220 & 820 & 208 & 27 & 102 & 42 & 0.0 & 218 & 200 & 47 & 2.4 & 15.0 & 0.2 & 38.0 & 9.40 \\
\hline 33 & Sitharampuram & $\mathrm{BW}$ & 7.4 & 2490 & 1618 & 104 & 1268 & 296 & 52 & 48 & 38 & 11.0 & 374 & 160 & 29 & 2.2 & 10.0 & 0.0 & 19.8 & 3.63 \\
\hline 34 & Gollapalli & DW & 7.3 & 2320 & 1508 & 210 & 980 & 208 & 59 & 53 & 23 & 16.0 & 231 & 160 & 57 & 2.2 & 10.0 & 0.0 & 22.1 & 4.58 \\
\hline & rage & & 7.46 & 1564 & 1010 & 131 & 496 & 144 & 43.3 & 75.8 & 20.4 & 4 & 347.2 & 150 & 51.2 & 1.40 & 2.20 & 0.02 & 36.2 & 7.89 \\
\hline & Maximum & & 8.0 & 3100 & 2015 & 220 & 1268 & 364 & 81 & 141 & 56 & 20 & 488 & 480 & 92 & 2.6 & 15 & 0.3 & 60.9 & 13.9 \\
\hline & Minimum & & 6.8 & 470 & 305 & 72 & 220 & 28 & 19 & 26 & 0 & 0 & 185 & 28 & 26 & 0.4 & 0 & 0 & 17.5 & 0.06 \\
\hline
\end{tabular}

The evaluation of groundwater for the irrigation purposes, depends upon the dissolved salts, relative proportion of bicarbonate to calcium and magnesium, relative proportion of sodium to calcium on the plant and soil, dominant climatic conditions, irrigation techniques, and drainage system (Todd, 2001). The suitability of water for irrigation is dependent upon such factors as soil texture and composition, crop grown and irrigation practices in addition to chemical characteristics of the water. For determination of suitability for irrigation use SAR\%, Na\% were calculated and plotted on Wilcox diagram (1955) and US Salinity Laboratory diagram (1954). The Wilcox's diagrams are prepared by plotting the sodium percentage (Na\%) against electrical conductivity (EC) (Fig.4). The US Salinity Laboratory diagram sodium adsorption ratio (SAR) is plotted on vertical axis and Electrical Conductivity (EC) on horizontal axis (Fig.5). The total dissolved solids content, 
measured in terms of specific electrical conductance, excessive sodium content in water renders it unsuitable of soils containing exchangeable $\mathrm{Ca}+++\mathrm{Mg}+++\mathrm{Na}++$ is considerably above 50 in irrigation waters, soils containing exchangeable calcium and magnesium causing deflocculation and impairment of the filth and permeability of soils. The US salinity diagram is divided into four distinct fields both vertical axis sodium (alkali) hazard divided into low sodium water (S1), medium (S2), high (S3), and very high sodium water (S4) (Table.2). Generally low sodium water can be used for irrigation purposes on the horizontal axis salinity hazard is divided into four groups low (C1), medium (C2), high (C3), and very high salinity (C4) water (Table.3). Low salinity water can be used for irrigation purpose for most crops, high and very high salinity water is unfavorable for irrigation purpose.

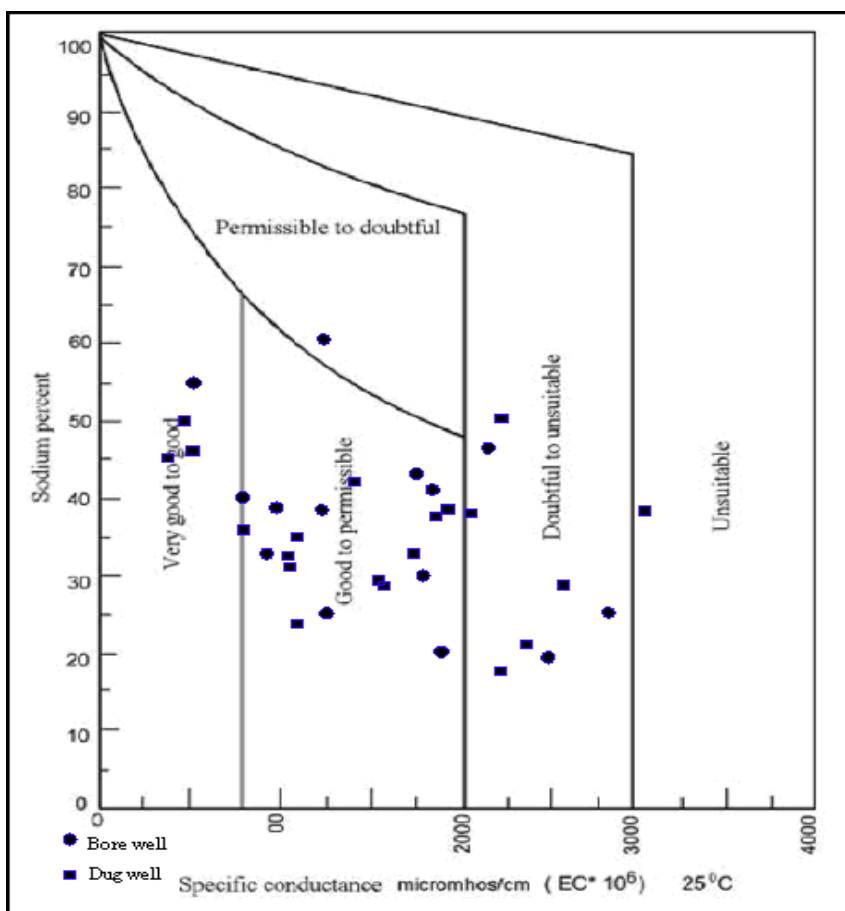

Fig. 4 Plotting of EC Vs Na\% on Wilcox's diagram (1955)

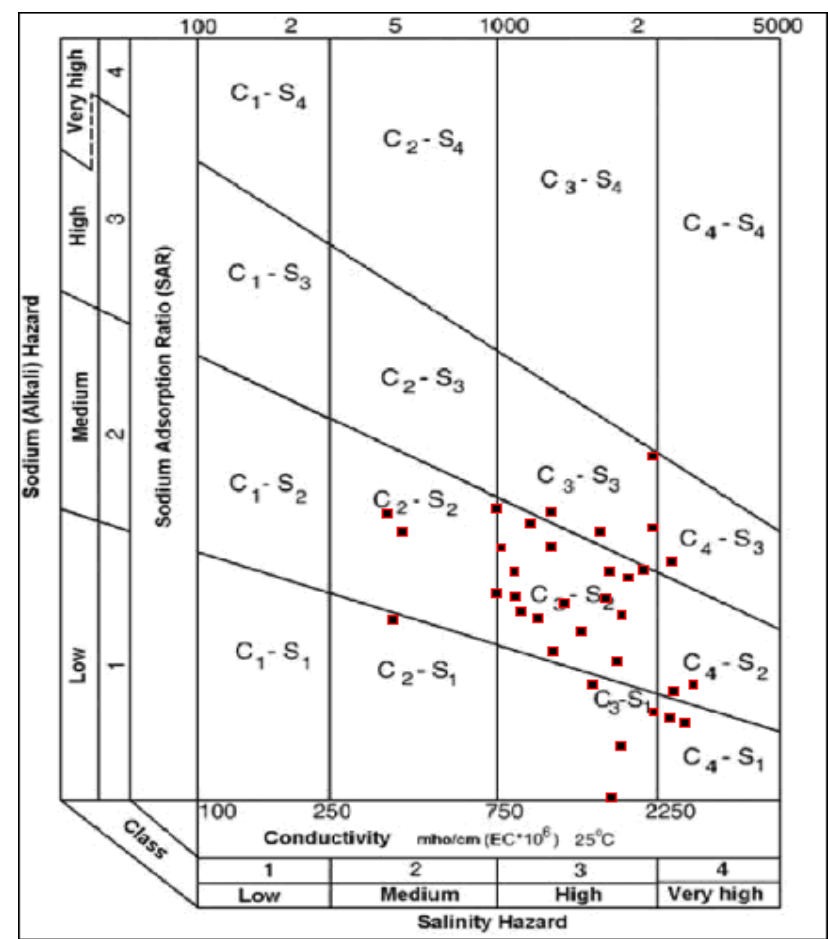

Fig.5. Plotting of sample data on US Salinity laboratory diagram 
Table 2. Irrigation water classification based on sodium content

\begin{tabular}{ll} 
Classification & \multicolumn{1}{c}{ Comment } \\
\hline S1 & $\begin{array}{l}\text { Low sodium water can be used for irrigation on almost all soils with little danger of the development of harmful } \\
\text { levels of exchangeable sodium. However, sodium-sensitive crops such as stone fruit trees and avocado may } \\
\text { accumulate injurious concentration of sodium. }\end{array}$ \\
S2 & $\begin{array}{l}\text { Medium sodium water will present an appreciable sodium hazard in fine textured soils having high cation } \\
\text { exchange capacity, especially under low leaching conditions, unless gypsum is present in the soil. This water } \\
\text { can be used on coarse-textured or organic soils with good permeability. }\end{array}$ \\
S3 & $\begin{array}{l}\text { High sodium water may produce harmful levels of exchangeable sodium in most soils and will require special } \\
\text { soil management good drainage, high leaching, and organic matter additions. Gypsiferous soils may not develop } \\
\text { harmful levels of exchangeable sodium except that amendments may be required for replacement of } \\
\text { exchangeable sodium except that amendments may not be feasible with waters of very high salinity. }\end{array}$ \\
Very high sodium water is generally unsatisfactory for irigation purposes except at low and perhaps medium \\
salinity, where the dissolving of calcium from the soil or the use of gypsum or other additives may make the use \\
of these waters feasible.
\end{tabular}

Table 3. Groups of irrigation waters based on electrical conductivity

\begin{tabular}{|c|c|c|c|}
\hline $\operatorname{TDS}(\mathrm{mg} / 1)$ & $\begin{array}{l}\mathrm{ECx} 10^{6} \\
\text { at } 25^{0} \mathrm{C}\end{array}$ & Class & Remarks \\
\hline$<200$ & $<250$ & $\mathrm{C} 1$ & $\begin{array}{l}\text { Low salinity water-can be used for irrigation with most crops on most soils with little } \\
\text { likelihood that a salinity problem will develop. Some leaching is required, but this occurs } \\
\text { under normal irrigation practices except in soils of extremely low permeability. }\end{array}$ \\
\hline $200-500$ & $250-750$ & $\mathrm{C} 2$ & $\begin{array}{l}\text { Medium salinity water can be used if a moderate amount of leaching occurs. Plants with } \\
\text { moderate salt tolerance can be grown in most instances without special practices for } \\
\text { salinity control. }\end{array}$ \\
\hline $500-1500$ & $750-2250$ & $\mathrm{C} 3$ & $\begin{array}{l}\text { High salinity water-cannot be used on soils with restricted drainage, special management } \\
\text { for salinity control may be required and plants with good salts tolerance should be } \\
\text { selected. }\end{array}$ \\
\hline $1500-3000$ & $2250-5000$ & $\mathrm{C} 4$ & $\begin{array}{l}\text { Very high salinity water-is not suitable for irrigation under ordinary conditions but may } \\
\text { be used occasionally under very special circumstances. The soil must be permeable, } \\
\text { drainage must be adequate, and irrigation water must be applied in excess to provide } \\
\text { considerable leaching, and very salt-tolerant crops should be selected. }\end{array}$ \\
\hline
\end{tabular}

After U.S. Salinity laboratory, 1954.

The overall samples with regard to sodium and salinity hazard are represented in the Table 4 .

Table 4 Showing sodium and salinity hazards

\begin{tabular}{|c|c|c|}
\hline S.No & No. of Samples & Field \\
\hline 1 & 1 & C2-S1 \\
\hline 2 & 4 & C2-S2 \\
\hline 3 & 4 & C3-S1 \\
\hline 4 & 16 & C3-S2 \\
\hline 5 & 4 & C3-S3 \\
\hline 6 & 2 & C4-S1 \\
\hline 7 & 2 & C4-S2 \\
\hline 8 & 1 & C4-S3 \\
\hline
\end{tabular}

Thus from the above classification most of the water samples indicate the ground water of Yeshwanthapur subbasin is moderate water.

\section{Results And Discussion}

The analytical results and statistical parameters derived from hydrochemical parameters in the groundwater of the Yeshwanthapur sub-basin are presented in the Table.1. $\mathrm{pH}$ values in the basin range from 6.8 to 8.0 indicating groundwater of the basin is normal to slightly alkaline in nature. The specific Electrical Conductance (EC) values range from 470 to $3100 \mu \mathrm{mhos} / \mathrm{cm}$ and higher values indicate that ionic concentration 
is more. Total Dissolved Solids (TDS) vary from $305 \mathrm{mg} / \mathrm{l}$ to $2015 \mathrm{mg} / \mathrm{l}$ are slightly saline. Fluoride concentration in the sub-basin is ranging from 0.4 to $2.6 \mathrm{mg} / \mathrm{l}$ and average is $1.4 \mathrm{mg} / \mathrm{l}$ some of the samples are identified with above permissible limit in the sub-basin due to the disintegration of biotite, apatite and fluoride minerals present in the acid rocks like granites these are not useful for drinking purpose. In few samples concentration of Calcium, Magnesium, Potassium Sodium Carbonates and Bicarbonates are within permissible limits where as Chlorides Sulphates and Nitrates are above the permissible limits.

\section{Groundwater quality for determination of Irrigation use}

\section{Percent Sodium:}

To determine the suitability for irrigation use in groundwater is by calculating $\mathrm{Na}+$ percentage (Wilcox, 1955), because $\mathrm{Na}+$ concentration reacts with soil to reduce its permeability (Todd, 1980).

Percent Sodium is calculated as:

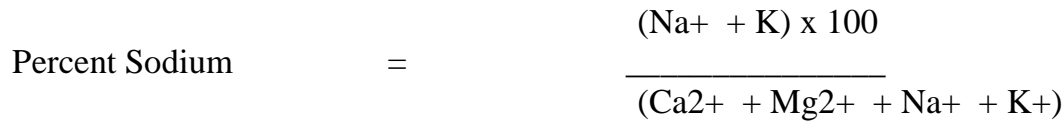

Where, the concentration is expressed in meq/l.

According to Wilcox classification 6 samples falling under very good to good, 18 samples are under good to permissible, 1 sample under permissible too doubtful, 8 samples are under doubtful to unsuitable, and 1 sample falling unsuitable category (Table.5). Percent Sodium plotted on Wilcox diagram indicates that out of 34 samples, 24 samples belong to very good to permissible category, 08 samples belong to doughtful and 1 sample belong to unsuitable category.

Table 5 Irrigation water classification according to $\mathrm{Na} \%$

(Wilcox, 1955)

\begin{tabular}{|c|c|c|}
\hline Na\% & Water Class & Sample \% \\
\hline$<201$ & Very good & 6 \\
\hline $20-40$ & Good & 18 \\
\hline $40-60$ & Permissible & 1 \\
\hline $60-80$ & Doubtful & 8 \\
\hline$>80$ & Unsuitable & 1 \\
\hline
\end{tabular}

\section{Sodium Adsorption Ratio (SAR):}

Another method for determination of suitability for agricultural use in groundwater is by calculating SAR values. Sodium Adsorption Ratio (SAR) is the value of adsorption of Na by soil constituents during water percolation. This ratio has certain advantages for use as an index of the sodium or alkali hazard of the water (Todd, 2001). A higher value of SAR leads to damage of soil structure (Suresh, 1994; Todd, 2001). Alkali hazard in soils is promoted by high SAR and is reversed by water containing high calcium and magnesium.

The SAR is defined and obtained by

$$
\text { SAR }=-\frac{\mathrm{Na}}{\sqrt{(\mathrm{Ca}+\mathrm{Mg} / 2)}}
$$

Where, all the ions are expressed in Meq/l.

The SAR values in the area ranges between 0.06 and 13.9. According to the standards given in the Table No. 6 , all the samples are falling in the class of excellent to good category.

Table 6 Irrigation classification of groundwater according to SAR values

\begin{tabular}{|l|l|l|}
\hline SAR & Water Class & Sample \% \\
\hline$<10$ & Excellent (S1) & 24 \\
\hline $10-18$ & Good (S2) & 10 \\
\hline $18-26$ & Doubtful (S3) & 0 \\
\hline$>26$ & Unsuitable (S4) & 0 \\
\hline
\end{tabular}

Based on the above analysis the groundwater of the area contains higher concentration of $\mathrm{K}, \mathrm{Ca}, \mathrm{Na}$, $\mathrm{Mg}$ and chloride. The $\mathrm{K}, \mathrm{Ca}$, and $\mathrm{Na}$ might have been released by the chemical weathering of both the $\mathrm{k}-$ feldspars and plagioclases present in the country rocks i.e., granites and granitic gneisses. The high concentration of $\mathrm{Mg}$ and Chlorides may be due to the alteration of ferro-magnesium minerals present in the gneisses. The groundwater is mostly neutral to slightly alkaline character. The excess fluoride may be due to the presence of fluorite, mica, and apatite minerals present in the granites. 
Further, they are mostly suitable for agriculture. However, they are less suitable for drinking purpose since they have high concentration of fluoride and total hardness.

\section{Conclusions}

An Interpretation of hydrochemical analysis for groundwater quality and evolution of hydrochemical facies in the yeshwanthapur sub-basin reveals that concentrations of the major ions and important physical parameters are within the permissible limits for irrigation SAR values range from $0.06 \mathrm{mg} / \mathrm{l}$ to $13.9 \mathrm{mg} / \mathrm{l}$ and water falls in the class excellent to good category. Percent Sodium values indicate the most of groundwater samples belongs to very good to permissible category for irrigation on Wilcox diagram. Thus, the overall groundwater quality in the sub-basin is fresh and suitable for irrigation use.

\section{Reference}

[1]. APHA (1989) Standard methods for examination of water and wastewater $17^{\text {th }}$ (Eds.) American Public Health Association,

[2]. Washington, DC.

[3]. DONEEN, LD. (1961) The influence of crop and soil on percolating waters. Proc. Groundwater Recharge Conference, California, USA.

[4]. HEM, J.D. (1985) Study and interpretation of the chemical characteristics of natural water. US Geol. Water Supply pp.2254, 263,

[5]. USGS, Washington.

[6]. SALEH, A., Al-RUWAIH, F. and SHEHATA, M. (1999) Hydrogeochemical processes operating within the main aquifers of Kuwait.J.Arid Env. V.42, pp. 195-209.

[7]. TODD, D.K. (1980) Groundwater Hydrology. $2^{\text {nd }}$ Edn. John Wiley \& Sons, Inc, New York.

[8]. WILCOX, L.V. (1955) Classification and use of irrigation water. U.S. Geol. Surv. Depart of Agriculture, Washington D.C. Circular No.969, 19.

IOSR Journal of Applied Geology and Geophysics (IOSR-JAGG) is UGC approved Journal with Sl. No. 5021, Journal no. 49115.

B. Satheesh. "Assessment of Groundwater Quality for Irrigation Use and Evolution of Hydrochemeical Facies in the Yeshwanthapur Sub-Basin, Warangal Dist." IOSR Journal of Applied Geology and Geophysics (IOSR-JAGG) 5.4 (2017): 14-20. 